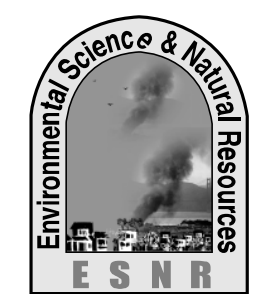

\section{Comparison of Performance between Organic Farming and Traditional Farming of Freshwater Prawn in Respect of Production and Economics}

\author{
M. R. Haque ${ }^{1 *}$, N. Nahar ${ }^{2}$, R. Pervin ${ }^{1}$ and M. A. Samad ${ }^{3}$ \\ ${ }^{1}$ Department of Fisheries Management, \\ Hajee Mohammad Danesh Science and Technology University, Dinajpur \\ ${ }^{2}$ Department of Fisheries, GOB \\ ${ }^{3}$ Department of Fisheries, Rajshahi University, Rajshahi \\ *Corresponding author: rezoanfm@yahoo.com
}

\begin{abstract}
An experiment was conducted to compare the performance between traditional farming and organic farming of freshwater prawn in respect of production and economics. The experiment had two treatments, namely: Traditional (TT) and Organic (TO) with same stocking density (20000 juvenile's ha $\left.^{-1}\right)$ in triplicate. In treatment TO, formulated feed with locally available ingredients were used, and maize flour and bamboo branches were provided for maintaining $\mathrm{C}: \mathrm{N}$ ratio to 20 and for developing periphyton, respectively. In treatment TT, only commercially available prawn feed was applied. No fertilizers or other types of chemicals or antibiotics were used in both treatments. There were no significant differences $(\mathrm{P}>0.05)$ of different water quality parameters between both treatments. Weight gain and specific growth rate $\left(\%\right.$ body weight day $\left.{ }^{-1}\right)$ of prawn was significantly higher $(\mathrm{P}<0.05)$ in TO than TT treatment. Survival rate and feed conversion ratio of prawn did not vary significantly between both treatments. Highest total yield was obtained from TO treatment (511.41 $\left.\mathrm{kg} \mathrm{ha}^{-1} 90 \mathrm{~d}^{-1}\right)$ compared to TT treatment $\left(426.57 \mathrm{~kg} \mathrm{ha}^{-1} 90 \mathrm{~d}^{-1}\right)$. Net yield was also significantly higher in treatment TO $\left(428.32 \mathrm{~kg} \mathrm{ha}^{-1} 90 \mathrm{~d}^{-1}\right)$ than TT $\left(347.77 \mathrm{~kg} \mathrm{ha}^{-1} 90^{-1}\right)$. Although there was no significant difference in benefit-cost ratio between both treatments, totalreturn was significantly higher in TO than TT treatment.
\end{abstract}

Key word: Freshwater prawn, Macrobrachium rosenbergii, Organic farming, Production, Traditional farming

\section{Introduction}

Freshwater prawn has been appeared as a major aquaculture species in many countries including China, India, Indonesia, Vietnam, Bangladesh and Equador after its domestication in 1960s (Fatema et al., 2011). Bangladesh is considered as one of the most suitable countries for giant freshwater prawn (Macrobrachium rossenbergii) farming, because of its favorable agroclimatic condition. Bangladesh has entered into the commercial prawn farming in early 1990s and has become a world player as one of the seven major export countries (Wahab, 2009) .Due to favorable climate, abundant low lying rice fields, availability of seeds and other water resources, Bangladesh can now dream to be a dominant producer after China and India. There is a difference between organic farming and traditional farming of prawn. The increase in world aquaculture production has recently seen the negative impacts of unsustainable production methods in many countries with regard to the environment and in some cases, consumer's safety. Traditional and unplanned prawn culture has serious impact on the environment. Due to increase awareness, in many European Union countries, consumers are becoming more anxious about the food they eat and are increasingly concerned with food production issues such as food safety (Haung, 1995), food quality (Haglund et al. 1999), and animal welfare (Fearne and Lavelle, 1996). Consumers of developed countries are turning their interest to the organically produced aquatic products. Therefore, countries like Vietnam, Thailand, Indonesia, and Ecuador have quickly responded to the demands of the export markets and converted their culture system for growing organic shrimp and began to penetrate these markets with their goods. In the late $1990 \mathrm{~s}$, in response to the negative environmental and social consequences of modern farming methods, the world's first organic shrimp farm was created in Ecuador. Bangladesh and other South
Asian countries are still far behind to catch up the growing organic markets. Moreover, demand for organic fish and shellfish is also expected to grow in the Asian markets. Thus, Bangladesh urgently needs to promote organic aquaculture for expanding the present export market.

Organic farming protects the health of consumers by reducing the overall exposure to toxic chemicals from pesticides that can accumulate in the ground, air, water and food supply. Organic prawn farming is an important way of moving towards the goal of sustainability. Moreover, sustainable prawn farming will not only help to ensure that resources are recycled and maintained but also overseas market access is improved, as consumers increasingly demand that food be produced in an environmentally sustainable system. Organic prawn can contribute to increased export and domestic market earning by supplying a particular market niche with a product perceived as high quality by environmentally aware consumers. Organic prawns provide a recognizable alternative for those consumers seeking food with little or no chemical residues.

The use of periphyton substrates and manipulation of $\mathrm{C}: \mathrm{N}$ ratio as an approach of organic culture in freshwater prawn production has been found promising. These techniques require installation of hard substrates or application of cheap carbohydrates which could potentially be produced within the farmers' traditional systems. Substrates based system can increase freshwater prawn production to a significantly higher level when compared to traditional production system (Tidwell and Bratvold, 2005). Cohen et al. (1983) reported that added substrate in ponds increased prawn production by $14 \%$ and average size by $13 \%$. Experiments conducted in Bangladesh showed that vertical substrate addition resulted in prawn survival increased $75 \%$ and production $127 \%$ prawn in -tilapia 
polyculture system (Uddin et al., 2006). The benefits exerted from periphyton-based ponds are periphyton as additional natural food, substrate as shelter to minimize territorial effects and improved water quality through trapping suspended solids, organic matter breakdown and enhanced nitrification. On the other hand, prawn is fed with a specially formulated organic food which contains no drugs and has locally available low cost raw materials free from GM and artificial chemicals and a high $\mathrm{C}: \mathrm{N}$ ratio is maintained by using low cost maize flour.

Trials with periphyton-based aquaculture in freshwater ponds in Benin, West Africa gave significantly higher annual fish yields, as compared with production from other rural ponds managed for aquaculture (Hem et al., 1994). Consequently, this innovative pond management strategy was proposed as a suitable technique to increase fish production in rural ponds in South Asia, particularly in Bangladesh and India. Enhancement of periphyton by providing artificial substrates in the aquaculture systems is a simple and may be a cheaper way to increase production. It is an efficient way of producing fish as the food chain is reduced to one trophic level and the energy losses are minimized.

Considering the importance of organic farming by periphyton-based systems and manipulating the C:N ratio in organic feed for culture of freshwater prawn, and paucity of information of previous works, the present study was designed to compare the performance between organic farming and the traditional farming of freshwater prawn in respect of production and economics. The ultimate objective of this experiment was to establish an organic farming method of freshwater prawn in a cost effective way. If the organic farming method of prawn is found better in respect of production and economics through this experiment, it can be followed by the prawn farmers of Bangladesh so that present export markets would be expanded.

\section{Materials and Methods}

\section{Experimental design}

The experiment was conducted using a completely randomized block design into two treatments with three replications for each. Stocking density of prawn juvenile was same in both treatments (Table 3.1). The differences between both treatments were in the management practices. The treatments were traditional and organic farming of prawn. The treatment of traditional farming is abbreviated as TT and the organic farming as TO.

In treatment TO, formulated feed with the locally available ingredients was used, and maize flour and bamboo kanchi were provided for maintaining $\mathrm{C}: \mathrm{N}$ ratio 20 and developing periphyton, respectively. But in treatment TT, commercially available prawn feed was applied, and maize flour and bamboo branches (kanchi) were not supplied. Rotenone, lime and fertilizer were used only during the preparation of ponds but no fertilizers or other types of chemicals or antibiotics were used in both treatments after stocking.
Table 1. Experimental design

\begin{tabular}{lcc}
\hline Variables & \multicolumn{2}{c}{$\begin{array}{c}\text { Treatments (Stocking } \\
\text { density /ha) }\end{array}$} \\
\cline { 2 - 3 } & TT & TO \\
\hline Freshwater prawn & $\begin{array}{c}20,000 \\
\text { Commercial }\end{array}$ & $\begin{array}{c}\text { Locally } \\
\text { formulated }\end{array}$ \\
\hline
\end{tabular}

\section{Experimental site and pond preparation}

The experiment was carried out at the pond facilities of Fisheries Field Laboratory of the Faculty of Fisheries, Bangladesh Agricultural University (BAU), Mymensingh for a period of 90 days from 31 August to 28 November 2009. Six rectangular earthen ponds with an area of $130 \mathrm{~m}^{2}$ and an average depth of $1.2 \mathrm{~m}$ each were used for this research. The ponds were rain-fed, well exposed to prevailing sunlight and being used for research over last 20 years. All unwanted fishes were eradicated by rotenone application at the rate of $100 \mathrm{~g}$ pond $^{-1}$. Lime $\left(\mathrm{CaCO}_{3}\right)$ was applied to all ponds at the rate of $250 \mathrm{~kg} \mathrm{ha}^{-1}$ on Day 1.

On day 4 , ponds were filled with groundwater from a deep tube-well. On day 6,12 side shoots of bamboo (locally known as kanchi) per $\mathrm{m}^{2}$ water surface area with a mean diameter of $2.8 \mathrm{~cm}$ were posted vertically into the bottom mud in TO ponds, excluding a 0.5 meter wide free perimeter. This resulted in an additional substrates surface area of $40 \mathrm{~m}^{2}$ for periphyton development equaling $60 \%$ of the pond surface area. On day 9, all ponds were fertilized with urea and triple super phosphate (TSP) at the rates of 100 and $100 \mathrm{~kg}$ $\mathrm{ha}^{-1}$, respectively. Ponds were left for 10 days postfertilization to allow plankton development in the water column and periphyton growth on substrates (treatment $\mathrm{TO}$ ), and subsequently stocked with prawns.

\section{Stocking and pond management}

In all ponds, post larvae (PL) of freshwater prawn (individual weight $5.47 \pm 0.02 \mathrm{~g}$ ) procured from a nearby commercial hatchery was stocked according to the experimental design $\left(2\right.$ prawns $\left.\mathrm{m}^{-2}\right)$. No fertilizers were used after stocking in both treatments.

In case of treatment TO, a locally formulated and prepared pellet feed $(2 \mathrm{~mm})$ containing about $24 \%$ protein (\% dry matter basis) with a $\mathrm{C} / \mathrm{N}$ ratio close to 15:1 was used. The feed was applied considering the body weight of prawn at a daily feeding rate of $10 \%$ body weight at the start of experiment, and gradually reduced to $5 \%$ body weight at the end of the culture period. Feed was distributed evenly over the pond's surface, twice daily at 7.00 to 18.00 hours. Individual weights of minimum $10 \%$ of initially stocked prawn in numbers were taken at monthly interval to estimate the biomass and adjust the feeding rate. Prawns were sampled using a cast net in both treatments but in treatment TO, it was done after eliminating some 
bamboo kanchi, which were re-positioned after the sampling.

In treatment $\mathrm{TO}$, locally purchased maize flour was used as carbohydrate source for manipulating the $\mathrm{C} / \mathrm{N}$ ratio to 20:1. The analysed proximate composition of feed and maize flour is given in Table 2. The preweighed maize flour was mixed with pond water in a beaker and evenly distributed over the pond surface directly after the application of feed at 07:00 and 18:00 hours.

Table 2. Proximate composition of the prepared feed and maize (percentages are given on dry weight basis)

\begin{tabular}{lllllll}
\hline Component & $\begin{array}{l}\text { Dry matter } \\
(\%)\end{array}$ & $\begin{array}{l}\text { Protein } \\
(\%)\end{array}$ & Lipid (\%) & Fiber (\%) & Ash (\%) & $\begin{array}{l}\text { Carbohydrate } \\
(\%)\end{array}$ \\
\hline Prepared feed & 91.31 & 24.27 & 10.00 & 6.15 & 20.61 & 30.28 \\
Maize flour & 88.92 & 7.72 & 4.64 & 5.40 & 1.14 & 70.02 \\
\hline
\end{tabular}

\section{Determination of water quality parameters}

Water samples were collected using a horizontal water sampler from three locations of each pond. Water quality parameters, temperature (degree Celsius, thermometer), dissolved oxygen (HACH Sension 8), $\mathrm{pH}$ (CORNING $445 \mathrm{pH}$ meter) and transparency (Secchi disc) were monitored in situ at $0900 \mathrm{~h}$ on a weekly interval. Total alkalinity (titrimetric method) and nutrients, $\mathrm{NO}_{2}-\mathrm{N}, \quad \mathrm{NO}_{3}-\mathrm{N}, \quad \mathrm{NH}_{3}-\mathrm{N}$ and $\mathrm{PO}_{4}-\mathrm{P}$ concentrations (HACH kit model DR 2010) were determined in the late morning (between 0900 to 1000 h) at monthly basis (APHA, 1992).

Before nutrient analysis, water samples were filtered through a glass microfibre filter paper (Whatman GF/C, Whatman International, Maidstone, England) using a vacuum pressure air pump. The filter papers containing particulate matter were preserved in $10 \mathrm{ml}$ of $90 \%$ acetone in a test tube and kept in refrigerator for 24 hours for subsequent chlorophyll $a$ analysis. The papers in the test tube were ground by using a glass rod, centrifuged (Denlay centrifuge, model BS-400) for 10 minutes at 3,000 rpm and made ready for chlorophyll $a$ analysis. Afterward, supernatant water was poured to a cuvette and chlorophyll $a$ was determined using spectrophotometer (Spectronic Genesys 5, model $336001)$ at 664 and $750 \mathrm{~nm}$ wave lengths, following Boyd (1979).

\section{Assessment of plankton population}

Plankton samples were collected monthly by pooling 10 Liter of water from five locations in each pond and passing it through a plankton net (mesh size $45 \mu \mathrm{m}$ ). The concentrated samples were preserved in small plastic bottles with $5 \%$ buffered formalin.

Plankton numbers were estimated using a SedgewickRafter (S-R) cell and was left to stand for 15 minutes to allow plankton to settle. Then, the planktons on 10 randomly selected fields of the chamber were counted under a binocular microscope (Swift, M-4000). Taxa were identified to genus level using keys from Bellinger (1992). Plankton abundance was calculated using the following formula (Azim et al., 2001):

$N=(P \times C \times 100) / L$
Where, $N$ is the number of plankton cells or units per liter of original water; $P$, the number of plankton counted in 10 fields; $C$, the volume of final concentrate of the sample $(\mathrm{ml}) ; L$, the volume $(\mathrm{L})$ of the pond water sample.

\section{Assessment of benthic macroinvertebrates}

The benthic invertebrate samples from the pond bottom muds were collected monthly using an Ekman dredge (area $225 \mathrm{~cm}^{2}$ at the lower mouth). The mud samples were taken randomly from three different locations in each pond and washed through a sieve $(250 \mu \mathrm{m}$ mesh size). Benthic invertebrates remaining on the sieve were separated and preserved in a plastic vial containing $10 \%$ buffered formalin solution. Identification keys used for benthic macroinvertebrates were from Pinder and Reiss (1983). Benthic macroinvertebrates density (individuals $/ \mathrm{m}^{2}$ ) were calculated using the following $\mathrm{g}$ formula (Asaduzzman et al., 2010):

$\mathrm{N}=\mathrm{Y} \times 10000 / 3 \mathrm{~A}$

Where, $\mathrm{N}=$ number of benthic organisms (number $\mathrm{m}^{-2}$ ); $\mathrm{Y}=$ total number of benthic organisms counted in 3 samples; $\mathrm{A}=$ area of Ekman dredge $\left(\mathrm{cm}^{2}\right)$.

\section{Taxonomic composition and biomass of periphyton}

From each pond, three kanchi poles were selected randomly and three $2 \times 2 \mathrm{~cm}$ samples of periphyton were taken at each of three depths $(25,50$ and $75 \mathrm{~cm}$ below from the water surface) per pole at monthly interval starting after 7 days of substrate installation. One of the three samples from three poles and three depths per pond per sampling day were pooled for dry matter (DM), ash and ash free dry matter (AFDM) analysis.

The other two pooled samples from three poles and three depths were employed for chlorophyll $a$ determination and taxonomic identification. Periphyton biomass and autotrophic index were analyzed following APHA (1992). Periphytic algae were calculated using a binocular microscope (Olympus, M-4000D, Tokyo, Japan) as described by Azim et al. (2001).

Harvesting of prawn and estimation of yield parameters

Prawns were harvested after draining the ponds. Individual length (wooden measuring board; precision 
$0.1 \mathrm{~cm}$ ) and individual weight (Denver-xp-3000; precision $=0.1 \mathrm{~g}$ ) were recorded. Specific growth rate (SGR), feed conversion ratio (FCR) and net yields were calculated as follows:

SGR $\left(\%\right.$ bw day $\left.^{-1}\right)=[(\ln$ final weight $-\ln$ initial weight) $\mathrm{x}$ 100]/ Culture periods (days)

FCR $=$ Feed applied (dry weight) /Live weight gain

Net yield $=$ Total biomass at harvest - Total biomass at stocking

\section{Economic analysis}

An economical analysis was performed to estimate the net return and benefit-cost ratio in both treatments. The following equation was used:

$$
\mathrm{R}=\mathrm{I}-(\mathrm{FC}+\mathrm{VC}+\mathrm{Ii})
$$

Where, $\mathrm{R}=$ net return, $\mathrm{I}=$ income from prawn and tilapia sale, $\mathrm{FC}=$ fixed/common costs, $\mathrm{VC}=$ variable costs and $\mathrm{Ii}=$ interest on inputs. The benefit cost ratio was determined by following equation:

Total input cost

Benefit cost ratio $(\mathrm{BCR})=$ Total net return /

The wholesale prices per $\mathrm{kg}$ of large, medium and small prawn were TK. 450, 300 and 200, respectively. The prices of inputs and prawn correspond to the Mymensingh wholesale market prices in July to December 2009 and are expressed in Bangladeshi taka $(1 \mathrm{US} \$=70 \mathrm{BDT})$.

\section{Statistical analysis}

Independent samples T-Test was performed for comparing water quality parameters, plankton, periphyton and benthic macorinvertibrates data, and growth and production of prawn and tilapias as well as economics between both treatments. Survival and percent data were analyzed using arcsine-transformed data, but percent values were reported. The assumptions of normal distribution and homogeneity of variances were checked before analysis. All statistical tests were carried out at a 5\% level of significance using SPSS (Statistical Package for Social Science) version 16.0

\section{Results and Discussion}

\section{Water quality parameters}

In fish culture, water quality is usually defined as the suitability of water for the survival and growth of fish. Mean values of water quality parameters did not differ significantly $(\mathrm{P}>0.05)$ between two treatments (Table 2 ). The mean values of water temperature were more or less close to the $27^{\circ} \mathrm{C}$ in each treatment. The recommended suitable range of temperature for prawn culture is $21.9^{\circ} \mathrm{C}$ to $33.5^{\circ} \mathrm{C}$ (Fair and Foftner, 1981).

Water transparency indicating sestonic food abundance found to be ranged from 23 to $61 \mathrm{~cm}$ in two treatments which were more or less similar with the findings of Kohinoor et al. (2001); Uddin (2002) who recorded values ranging from 15 to $58 \mathrm{~cm}$ and 11 to $63.5 \mathrm{~cm}$. The ranges of dissolved oxygen concentration (2.30 to 9.20
$\mathrm{mgL}^{-1}$ ) in two treatments exceeded the upper limit of the findings of Haque et al (2013) who recorded DO concentration 1.60 to $8.60 \mathrm{mgl}^{-\mathrm{I}}$. Wulff (1982) reported that juveniles of freshwater prawn could tolerate minimum oxygen levels of 1.0 to $1.5 \mathrm{mg}^{-1}$ and suggested not to allow the prawns at such levels for long time. The mean values of $\mathrm{pH}$ were $7.37 \pm 0.05$ and $7.28 \pm 0.04$ in treatments $T_{1}$ and $T_{2}$ respectively, which was more or less similar to the findings of Boyd and Zimmermann (1998), who reported that the ideal environment for nursing of prawn post-larvae should have $\mathrm{pH}$ values of 7 to 8.5 . It is also reported that $\mathrm{pH}$ ranged from 6.8 to 8.4 is suitable for Macrobrachium rosenbergii culture (Hossain et al., 2000). Water bodies having total alkalinity $40 \mathrm{ppm}$ or more are considered more productive than water bodies of lower alkalinity (Mairs, 1966).

According to Boyd (1982) total alkalinity should be more than $20 \mathrm{ppm}$ in fertilized ponds. Total alkalinity in the present study ranged from 74.00 to $120.00 \mathrm{mg} \mathrm{l}^{-1}$ in both treatments, indicating that total alkalinity in the present experiment might be considered as a suitable range for fish culture. The mean $( \pm \mathrm{SE})$ values of chlorophyll $a$ were more or less identical to the findings of Haque et al. (2013) but were lower compared to the findings of other authors in this region (Kadir et al., 2006; Milstein et al., 2006; Kunda, 2008; Rahman et al., 2010b;) might be due to lower values of total nitrogen limiting the algal biomass (Maclean et al., 1994).

The values of $\mathrm{NH}_{3}-\mathrm{N}$ in treatment $\mathrm{T}_{1}$ and $\mathrm{T}_{2}$ were 0.08 to $1.03 \mathrm{mg} \mathrm{l}^{-1}$ and 0.01 to $0.56 \mathrm{mg} \mathrm{l}^{-1}$ which are more or less similar to Rahman (2005) and Asaduzzaman et al. (2006) who recorded ammonia-nitrogen value ranged from 0.01 to 0.82 and 0.203 to $0.569 \mathrm{mg}^{-1}$, respectively. The ranges of $\mathrm{NO}_{3}-\mathrm{N}$ were found to varied from 0.010 to $0.06 \mathrm{mg} \mathrm{l}^{-1}$ and 0.020 to $0.06 \mathrm{mg} \mathrm{l}^{-1}$ in $\mathrm{T}_{1}$ and $\mathrm{T}_{2}$ treatments, respectively which are more or less similar to the finding of Asaduzzaman et al. (2005) and Haque et al. (2013). The mean $( \pm \mathrm{SE})$ values of $\mathrm{NO}_{2}-\mathrm{N}$ concentration were $0.004 \pm 0.005 \mathrm{mgl}^{-1}$ and $0.003 \pm$ $0.005 \mathrm{mg} \mathrm{l}^{-1}$ in $\mathrm{T}_{1}$ and $\mathrm{T}_{2}$ treatments, respectively which are comparable to the findings of Azim et al., (1995); Wahab et al. (1995); Haque et al. (2013)

Phosphate-phosphorous ( $\mathrm{mg} \mathrm{l}^{-1}$ ) were found to vary from 0.17 to $0.89 \mathrm{mg} \mathrm{l}^{-1}$ and 0.13 to $0.59 \mathrm{mg} \mathrm{l}^{-1}$ during the experiment in $T_{1}$ and $T_{2}$ treatments, respectively which are more or less agree with the findings of Wahab et al. (1995), Uddin (2002) and Alim (2005) who recorded phosphate-phosphorus values ranging from $0.09 \mathrm{mg} \mathrm{l}^{-1}$ to $5.2 \mathrm{mg} \mathrm{l}^{-1}, 0.03 \mathrm{mg} \mathrm{l}^{-1}$ to $4.46 \mathrm{mg} \mathrm{l}^{-1}$, respectively. The concentration of chlorophyll $a$ was found to vary from 7.14-82.85 $\mu \mathrm{g} \mathrm{l}^{-1}$ and 11.90 $43.70 \mu \mathrm{g}^{-1}$ during the experiment in $\mathrm{T}_{1}$ and $\mathrm{T}_{2}$ treatments, respectively which were more or less similar to Hasan (1998); Paul (1998) who found chlorophyll $a$ in pond waters range from 10 to $200 \mu \mathrm{g} \mathrm{l} \mathrm{l}^{-1}$. 


\section{Abundance of plankton and benthic macro-} invertebrates

The abundance of plankton and benthic macroinvertebrates in the culture system are influenced by a number of management factors. Among them fish species combinations in polyculture, stocking density and ratio, and the nutrient input quality and quantity are most important (Milstein, 1993; Diana et al., 1997).

Table 3. Mean $( \pm$ SE) values of measured water quality parameters

\begin{tabular}{|c|c|c|c|}
\hline \multirow{2}{*}{ Parameters } & \multicolumn{2}{|c|}{ Treatments } & \multirow{2}{*}{$\begin{array}{c}\text { Level of } \\
\text { Significance at } \\
5 \%\end{array}$} \\
\hline & $\mathbf{T}_{1}$ & $\mathbf{T}_{2}$ & \\
\hline Temperature surface $\left({ }^{\circ} \mathrm{C}\right)$ & $27.48 \pm 0.51$ & $27.33 \pm 0.52$ & \\
\hline Temperature bottom $\left({ }^{\circ} \mathrm{C}\right)$ & $26.20 \pm 0.40$ & $26.14 \pm 0.40$ & NS \\
\hline Transparency (cm) & $43.31 \pm 1.15$ & $42.02 \pm 1.61$ & NS \\
\hline $\mathrm{pH}$ range & $7.37 \pm 0.05$ & $7.28 \pm 0.04$ & NS \\
\hline Dissolved oxygen $\left(\mathrm{mg} \mathrm{l}^{-1}\right)$ & $4.66 \pm 0.21$ & $4.52 \pm 0.22$ & NS \\
\hline Total Alkalinity & $102.0 \pm 2.66$ & $99.42 \pm 3.21$ & NS \\
\hline Total $\mathrm{NH}_{3}-\mathrm{N}\left(\mathrm{mg} \mathrm{l}^{-1}\right)$ & $0.16 \pm 0.04$ & $0.19 \pm 0.04$ & NS \\
\hline $\mathrm{NO}_{3}-\mathrm{N}\left(\mathrm{mgl}^{-1}\right)$ & $0.018 \pm 0.003$ & $0.018 \pm 0.004$ & NS \\
\hline $\mathrm{NO}_{2}-\mathrm{N}\left(\mathrm{mgl}^{-1}\right)$ & $0.004 \pm 0.005$ & $0.003 \pm 0.006$ & NS \\
\hline $\mathrm{PO}_{4}-\mathrm{P}\left(\mathrm{mgl}^{-1}\right)$ & $0.43 \pm 0.06$ & $0.33 \pm 0.04$ & NS \\
\hline Chlorophyll $a\left(\mu \mathrm{g} \mathrm{l}^{-1}\right)$ & $36.57 \pm 6.62$ & $22.72 \pm 2.40$ & NS \\
\hline
\end{tabular}

$\mathrm{NS}=$ Means are not significantly different $(\mathrm{P}>0.05)$

Apart from these management factors, fish feeding habits have an important influence on the abundance of plankton and benthos, both directly by consumption and indirectly through influencing the food web and nutrient availability. The phytoplankton species composition identified in the present experiment was representative of that found in Bangladesh prawn farming in rice fields and ponds (Wahab et al., 2008; Kunda et al., 2008; Uddin, 2007). The more abundance of plankton in TO ponds then TT ponds may be due to the use of maize flour as $\mathrm{CH}$ source to maintain a high $\mathrm{C} / \mathrm{N}$ ratio. The carbohydrates source may increase the nutrients content of the TO ponds which in turn may enhance the abundance of plankton. The observed increase in the abundance of plankton during the first two months might be due to the increased nutrients in both treatments. The decrease in abundance of plankton after the second month might be attributed to increased grazing pressure by prawn in the both treatments. The observed lowest abundance of Chironomidae, Oligochaeta and total benthic macroinvertebrate in TT ponds might indicate that prawn directly feed on this benthic fauna. More abundance of benthos in TO ponds then the TT ponds also observed. This may be due to the availability of periphyton in organic culture ponds which may influence a decreased grazing pressure on benthos. The observed decrease in number of benthos during the culture period might be due to increased grazing pressure by prawn (Asaduzzaman et al., 2009). There is evidence that prawns in their natural habitats prefer to forage on animals like trochopterans, chironomids, oligochaetes, nematodes, gastropods and zooplankton (Corbin et al., 1983; Coyle et al., 1996; Tidwell et al., 1997).

\section{Periphyton biomass}

The quantitative production of periphyton was determined as dry matter (DM), ash free dry matter (AFDM) and chlorophyll $a$. The periphyton biomass increase in the first month followed by a continuous decrease until the end of the experiment may be accounted for by changes in the prawn grazing pressure on periphyton. The low biomass of prawn initially exerted low grazing pressure allowing periphyton to grow. As prawn grew its increased grazing pressure led to reduced periphyton biomass.

\section{Growth and production of prawn}

There was no significant difference in the mean survival rate of prawn between both treatments. So, this may be concluded that, substrate and organic feed with high carbohydrate content has no effects on the survival rate of prawn. This may be agreed with the findings of Tidwell et al. (2002) who reported that, substrate had no significant $(\mathrm{P}>0.05)$ impact on prawn survival. The gross and net yields of prawn were significantly higher in treatment TO than treatment TT. It is hypothesized that the periphyton grown on bamboo surface was a readily available feed, which might have enhanced the growth and production rate of freshwater prawn in the ponds with substrates compared to that of the ponds having no substrates. This has been reflected in the higher weight gain of fish in the ponds having bamboo substrates (Wahab et al., 1999). This is mainly because of additional shelter and natural food in the form of 
periphyton colonized on bamboo substrates along with improvements of environmental conditions through a range of ecological and biological processes (Tidwell et al., 2000; Tidwell et al., 2002; van Dam et al., 2002; Milstein et al., 2003). Cohen et al. (1983) reported that added substrate in ponds increased prawn production by $14 \%$ and average size by $13 \%$.

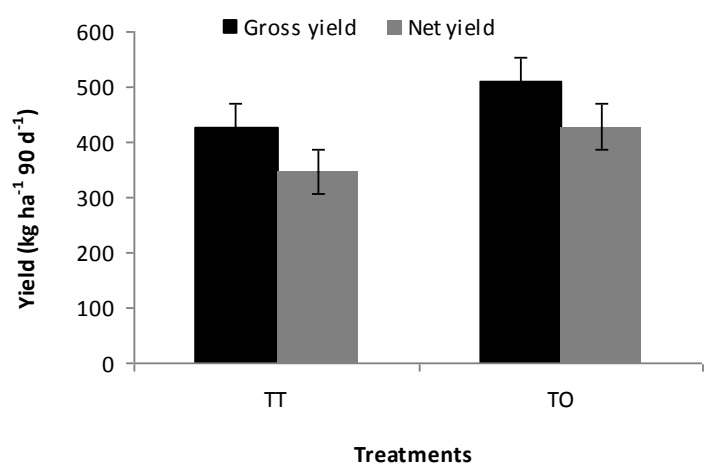

Fig. 1. Yield performance of freshwater prawn

Raanan et al. (1984) reported that added substrate was more effective in intensively stocked, aerated systems.
However, pond ecological and growth data revealed that maize flour can be a good source of organic carbon to maintain a high $\mathrm{C}: \mathrm{N}$ ratio for preparing organic feed. So, findings of the present study are agreed with the above authors.

\section{Economics}

The economic analysis revealed that the use of maize flour in organic feed reduced the carbohydrate cost thereby improved the economic benefits because the feed cost was $18 \%$ higher in treatment TT than treatment TO. Total return was $20 \%$ higher in treatment TO than TT. However, there was no significant difference in the net return between both treatments because substrate was an additional cost in TO. The economic benefit from TO may be increased further if the price rate of prawn from organic ponds might be increased in the export market due to the demand of organic products compared to the traditional products. On the other hand, market size of freshwater prawn should be at least $50 \mathrm{~g}$ which is not achieved in the present experiment due to short experimental periods.

Table 4. Abundance of plankton and benthos (mean $\pm \mathrm{SE}, \mathrm{N}=12$ ) with their different groups recorded in two treatments

\begin{tabular}{|c|c|c|c|}
\hline \multirow[b]{2}{*}{ Variables } & \multicolumn{2}{|c|}{ Treatments } & \multirow{2}{*}{$\begin{array}{c}\text { Level of } \\
\text { Significance } \\
\text { at } 5 \%\end{array}$} \\
\hline & $\mathbf{T}_{1}$ & $\mathbf{T}_{2}$ & \\
\hline \multicolumn{4}{|c|}{ Plankton ( $\times 1^{3}$ cells or colonies) } \\
\hline Bacillariophyceae & $23.58 \pm 1.39$ & $31.38 \pm 2.05$ & NS \\
\hline Chlorophyceae & $47.42 \pm 2.34$ & $53.00 \pm 2.21$ & NS \\
\hline Cyanophyceae & $29.42 \pm 2.37$ & $24.92 \pm 3.11$ & NS \\
\hline Euglenophyceae & $2.42 \pm 0.58$ & $2.42 \pm 0.46$ & NS \\
\hline Total phytoplankton & $102.83 \pm 4.01$ & $111.70 \pm 2.73$ & NS \\
\hline Rotifera & $3.33 \pm 0.56$ & $3.04 \pm 0.31$ & NS \\
\hline Crustacea & $1.04 \pm 0.22$ & $0.75 \pm 0.14$ & NS \\
\hline Cladocera & $6.21 \pm 0.77$ & $3.38 \pm 0.53$ & NS \\
\hline Total Zooplankton & $12.96 \pm 0.97$ & $9.08 \pm 0.65$ & NS \\
\hline Total plankton & $115.79 \pm 4.30$ & $120.79 \pm 2.47$ & NS \\
\hline \multicolumn{4}{|c|}{ Benthos (Individual $\mathbf{m}^{-2}$ ) } \\
\hline Chironomidae & $619.36 \pm 35.74$ & $682.80 \pm 28.89$ & NS \\
\hline Oligochaeta & $225.80 \pm 17.89$ & $258.90 \pm 23.69$ & NS \\
\hline Mollusca & $185.90 \pm 10.85$ & $199.73 \pm 19.43$ & NS \\
\hline Miscellaneous & $68.70 \pm 7.75$ & $53.59 \pm 5.03$ & NS \\
\hline Total & $1098.93 \pm 62.9$ & $1195.88 \pm 66.02$ & NS \\
\hline
\end{tabular}

$\mathrm{NS}=$ Means are not significantly different $(\mathrm{P}>0.05)$

Table 5. Mean $( \pm \mathrm{SE})$ values of periphyton quantitative parameters recorded from the sampling periods

\begin{tabular}{lllll}
\hline \multirow{2}{*}{ Parameters } & \multicolumn{4}{c}{ Sampling periods } \\
\cline { 2 - 5 } & $\begin{array}{l}\text { Initial } \\
\text { (August) }\end{array}$ & $\begin{array}{l}\text { Period 1 } \\
\text { (September) }\end{array}$ & $\begin{array}{l}\text { Period 2 } \\
\text { (October) }\end{array}$ & $\begin{array}{l}\text { Period 3 } \\
\text { (November) }\end{array}$ \\
\hline DM $\left(\mathrm{mg} \mathrm{cm}^{-2}\right)$ & $2.10 \pm 0.06$ & $2.15 \pm 0.03$ & $1.99 \pm 0.06$ & $1.77 \pm 0.05$ \\
AFDM $\left(\mathrm{mg} \mathrm{cm}^{-2}\right)$ & $1.40 \pm 0.05$ & $1.45 \pm 0.02$ & $1.37 \pm 0.03$ & $1.29 \pm 0.02$ \\
Chlorophyll $a\left(\mu \mathrm{g} \mathrm{cm}^{-2}\right)$ & $9.03 \pm 0.02$ & $9.45 \pm 0.03$ & $8.09 \pm 0.04$ & $7.00 \pm 0.04$ \\
\hline
\end{tabular}


Table 6. Comparison of growth and production parameters (mean $\pm \mathrm{SE}, \mathrm{N}=3$ ) of prawn in two treatments during a 90-day culture period

\begin{tabular}{lcc}
\hline \multicolumn{1}{c}{ Variables } & \multicolumn{2}{c}{ Treatments } \\
\cline { 2 - 3 } & $\mathrm{TT}$ & $\mathrm{TO}$ \\
\hline Individual stocking weight $(\mathrm{g})$ & $5.54 \pm 0.02^{\mathrm{a}}$ & $5.43 \pm 0.01^{\mathrm{b}}$ \\
Individual harvesting weight(g) & $29.98 \pm 0.21^{\mathrm{b}}$ & $33.67 \pm 0.44^{\mathrm{a}}$ \\
Individual weight gain $(\mathrm{g})$ & $24.44 \pm 0.19^{\mathrm{b}}$ & $28.02 \pm 0.43^{\mathrm{a}}$ \\
Specific growth rate $(\%$ bw d & $1.63 \pm 0.01^{\mathrm{a}}$ \\
Feed conversion ratio & $1.50 \pm 0^{\mathrm{b}}$ & $0.36 \pm 0.01$ \\
Survival $(\%)$ & $0.40 \pm 0.02$ & $76.41 \pm 1.68$ \\
Gross yield $\left(\mathrm{kg} \mathrm{ha}^{-1} 90 \mathrm{~d}^{-1}\right)$ & $71.15 \pm 1.11$ & \\
Large $(\geq 50 \mathrm{~g})$ & & $469.07 \pm 16.99^{\mathrm{a}}$ \\
Medium $(33.3-49.9 \mathrm{~g})$ & $395.70 \pm 5.93^{\mathrm{b}}$ & $31.97 \pm 5.48$ \\
Small $(\leq 33.2 \mathrm{~g})$ & $22.18 \pm 2.32$ & $10.38 \pm 1.00$ \\
Total & $8.69 \pm 1.17$ & $511.41 \pm 12.72^{\mathrm{a}}$ \\
Net yield $\left(\mathrm{kg} \mathrm{ha}^{-1} 90 \mathrm{~d}^{-1}\right)$ & $426.57 \pm 6.84^{\mathrm{b}}$ & $428.32 \pm 11.29^{\mathrm{a}}$ \\
\hline
\end{tabular}

*Mean values with different superscripts indicate a significant difference $(\mathrm{P}<0.05)$

Table 7. Comparison of economics (mean $\pm \mathrm{SE}, \mathrm{N}=3$ ) of two treatments calculated on the basis of 1 ha pond and 90 days' experimental periods. Currencies are given in Bangladeshi Taka, BDT (1 US\$ = 70 BDT)

\begin{tabular}{|c|c|c|c|c|}
\hline \multirow[t]{2}{*}{ Variables } & \multirow[t]{2}{*}{ Amount } & \multirow[t]{2}{*}{ Price rate } & \multicolumn{2}{|c|}{ Treatments } \\
\hline & & & TT & TO \\
\hline \multicolumn{5}{|l|}{ (A) cost } \\
\hline Land rental cost & 1 ha & $21000 \mathrm{ha}^{-1} \mathrm{y}^{-1}$ & $6000 \pm 0$ & $6000 \pm 0$ \\
\hline Prawn juveniles & $20000 \mathrm{ha}^{-1}$ & 4 juvenile $^{-1}$ & $80000 \pm 0$ & $80000 \pm 0$ \\
\hline Rotenone & $12.5 \mathrm{~kg}$ & $220 \mathrm{~kg}^{-1}$ & $2750 \pm 0$ & $2750 \pm 0$ \\
\hline Lime & $250 \mathrm{~kg}$ & $10 \mathrm{~kg}^{-1}$ & $2500 \pm 0$ & $2500 \pm 0$ \\
\hline Urea & $100 \mathrm{~kg}$ & $10 \mathrm{~kg}^{-1}$ & $1000 \pm 0$ & $1000 \pm 0$ \\
\hline TSP & $100 \mathrm{~kg}$ & $25 \mathrm{~kg}^{-1}$ & $2500 \pm 0$ & $2500 \pm 0$ \\
\hline Fuel cost & 500 units & 4 unit $^{-1}$ & $2000 \pm 0$ & $2000 \pm 0$ \\
\hline $\begin{array}{l}\text { Substrates (reuse- } 5 \\
\text { times) }\end{array}$ & $120000 \mathrm{P}$ & 1 piece $^{-1}$ & 0 & $24000 \pm 0$ \\
\hline Labor & & 120 man $^{-1}$ day $^{-1}$ & $4000 \pm 0$ & $5000 \pm 0$ \\
\hline Feed & & $25 / 20 \mathrm{~kg}^{-1}$ & $41912.58 \pm 988.04^{\mathrm{a}}$ & $35414.87 \pm 472.87^{\mathrm{b}}$ \\
\hline $\begin{array}{l}\text { Interest on inputs (4 } \\
\text { months) }\end{array}$ & & $12 \%$ annually & $5706.50 \pm 39.52$ & $6446.60 \pm 18.91$ \\
\hline $\begin{array}{l}\text { Total cost (A) } \\
\text { (B) Benefit (return) } \\
\text { Prawn sale }\end{array}$ & & & $148369.10 \pm 1027.56^{\mathrm{b}}$ & $167611.50 \pm 491.78^{\mathrm{a}}$ \\
\hline Large $(\geq 50 \mathrm{~g})$ & & $450 \mathrm{~kg}^{-1}$ & $178066.50 \pm 2669.03^{b}$ & $211080.00 \pm 7648.33^{\mathrm{a}}$ \\
\hline Medium $(33.3-49.9 \mathrm{~g})$ & & $300 \mathrm{~kg}^{-1}$ & $6654.00 \pm 696.96$ & $9591.00 \pm 1643.98$ \\
\hline Small $(\leq 33.2 \mathrm{~g})$ & & $200 \mathrm{~kg}^{-1}$ & $1738.97 \pm 233.42$ & $2076.67 \pm 198.14$ \\
\hline Total benefit (B) & & & $186459.20 \pm 2871.69^{\mathrm{b}}$ & $222747.70 \pm 6274.17^{\mathrm{a}}$ \\
\hline (C) Profit (B - A) & & & $38090.08 \pm 3509.99$ & $55136.21 \pm 5919.02$ \\
\hline $\begin{array}{l}\text { (D) Benefit cost ratio, } \\
\text { BCR (B/A) }\end{array}$ & & & $1.26 \pm 0.02$ & $1.33 \pm 0.03$ \\
\hline
\end{tabular}

Mean values with different superscripts in each row indicate a significant difference $(\mathrm{P}<0.05)$. 


\section{Conclusions}

Based on the findings of the present research, organic feed in addition of maize flour can be considered as a cheap diet. The findings of the present research confirmed that organic farming improved the natural food utilization efficiency and pond productivity. In the present study, it was not possible to estimate the contribution of artificial feed and different types of natural food to the growth of freshwater prawn. The result of the present study could be useful in improving the productivity of freshwater prawn in organic farming system. There exists scope for improvement of economic benefit of this technology by using other low cost feed ingredients and carbohydrate sources and cheaper on-farm periphyton substrates. The economic benefit from TO may be increased further if the price rate of prawn from organic ponds might be increased in the export market due to the demand of organic products compared to the traditional products. Moreover, further research is required for improvement of economic sustainability of organic farming.

\section{References}

Alim, M. A. 2005. Developing a polyculture technique for farmers consumption and cash crop. Ph.D. dissertation, Dept. of Fisheries Management, Bangladesh Agricultural University, Mymensingh, 192 p.

APHA. 1992. Standard Methods for the Examination of Water and Waste Water. $18^{\text {th }}$ edition. American Public Health Association, Washington, D. C, 1268 p.

Asaduzzaman, M.; Salam, M. A.; Wahab, M. A.; Kunda, M. and Rahman, M. B. 2006. Effects of control of $\mathrm{C} / \mathrm{N}$ ratio by low-cost carbohydrate addition on water quality and pond ecology in freshwater prawn, Macrobrachium rosenbergii post-larve nursing system. Bangladesh Journal of Fisheries Research, 10(2):121-130.

Asaduzzaman, M.; Yang, Y.; Wahab M. A.; Diana J. S. and Ahmed, Z. F. 2006. Farming system of giant freshwater prawn, Macrobrachium rosenbergii in Bangladesh: a combination of tradition and technology. Proceeding of the WAS Conference (AQUA 2006) held on 9-13 May in Florence, Italy.

Asaduzzaman, M. 2005. The potentials of organic farming of giant freshwater prawn, Macrobrachium rosenbergii in Bangladesh. M. S. dissertation, Dept. of Fisheries Management, Bangladesh Agricultural University, Mymensingh. 125 p.

Fair, P. H. and Foftner, A. R. 1981. The role of formulated feeds on natural productivity in culture of the prawn, Macrobrachium rosenbergii. Aquaculture, 24:233243.

Fearne, A. and Lavelle, D. 1996. Segmenting the UK egg market: results of a survey of consumer attitudes and perceptions. British Food Journal, 98(1):7-12.

Hassan, M. A. 1998. Development of carp polyculture techniques with small indigenous fish species mola, Amblypharyngodon mola; chela, Chela cachius, and punti, Puntius sophore. M.S. Thesis. Department of Fisheries Management, Bangladesh Agricultural University, Mymensingh. 71 p.
Haglund, A.; Johannson L.; Berglund L. and Dahlstedt L. 1999. Sensory evaluation of carrots from ecological and conventional growing systems. Food Quality and preference, 10(2):23-29

Haung, C. L. 1995. Consumer preferences and attitudes towards organically grown produces. European Review of Agricultural Economics, 23(3):331-342.

Hem, S. and Avit, J. L. B. 1994. First results on acadjas enclos as an extensive aquaculture system (West Africa). Bull. Mar. Sci. 55:1038-1049.

Fatema, K.; Wahab, M. A.; Pervin, R.; Khan, M. S. R. and Roy, H. C. 2011. Comparison of growth and production performance between male and female giant freshwater prawn in combination with mola. Journal of Environ. Science \& Natural Resources, 4(2):137-142.

Kohinoor, A. H. M. 2000. Development of culture technology of three small indigenous fish-mola, Amblypharyngodon mola; punti, Puntius sophore and chela, Chela cachius with notes on some aspects of their biology. Ph. D. dissertation, Department of Fisheries Management, Bangladesh Agricultural University, Mymensingh. 363 p.

Kunda, M.; Azim, M. E.; Wahab, M. A.; Dewan S.; Roos, N. and Thilsted, S. H. 2008. Potential of mixed culture of freshwater prawn, Mascrobrachium rosenbergii and self-recruiting small species mola, Amblypharyngodon mola in rottional rice-fish-prawn culture systems in Bangladesh. Aquaculture Research, 39:506-517.

Mairs, D. F. 1966. A total alkalinity atlas for marine lake waters. Limnol. Oceanogr, 11:68-72.

Paul, S. 1998. Comparison between carp polyculture system with silver carp, Hypopthalmichthys molitrix. M.S. Thesis. Department of Fisheries Management, Bangladesh Agricultural University, Mymensingh. 85 p.

Tidwell, J. H. and Bratvold, D. 2005. Utility of added substrates in shrimp culture. In: Azim M.E., Verdegem M. C. J.; van Dam A. A. and Beveridge M. C. M. (eds.), Periphyton: Ecology, Exploitation and Management. CABI Publishing, Wallingford, UK. pp. 247-268.

Uddin, M. S.; Azim, M. E.; Wahab, M. A. and Verdegem, M. C. J. 2006. The potential of mixed culture of genetically improved farmed tilapia (GIFT), Oreochromis niloticus and freshwater prawn, Macrobrachium rosenbergii in periphyton-based systems, Aquaculture Research, 37:241-247.

Wahab, M. A.; Kunda, M.; Azim, M. E.; Dewan, S. and Thilsted, S.H. 2009. Evaluation of freshwater prawnsmall fish culture concurrently with rice in Bangladesh. Aquaculture Reserach, 39:1524-1532.

Wahab, M. A.; Ahmed, Z. F.; Islam, A. and Rahmatullah, S. M. 1995. Effect of Common Carp, Cyprinus carpio (L) on the pond ecology and growth of fish in polyculture. Aquaculture Research, 26:619928.

Wulff, R. E. 1982. The experience of freshwater prawn farm in Honduras, Central Africa. In: New M.B. (eds.), Giant Prawn Farming, Development in Aquaculture and Fisheries Science, Eslevier Scientific publishing Co., Amsterdam, Elsevier, 10: 445- 448 